\title{
Intestinal Parasitosis and Under-nutrition in Ethiopia: Prevalence, Risk factors, and Prevention
}

Citation for published version (APA):

Mahmud, M. A. (2015). Intestinal Parasitosis and Under-nutrition in Ethiopia: Prevalence, Risk factors, and Prevention. [Doctoral Thesis, Maastricht University]. Datawyse / Universitaire Pers Maastricht. https://doi.org/10.26481/dis.20150311mm

Document status and date:

Published: 01/01/2015

DOI:

10.26481/dis.20150311mm

Document Version:

Publisher's PDF, also known as Version of record

\section{Please check the document version of this publication:}

- A submitted manuscript is the version of the article upon submission and before peer-review. There can be important differences between the submitted version and the official published version of record.

People interested in the research are advised to contact the author for the final version of the publication, or visit the DOI to the publisher's website.

- The final author version and the galley proof are versions of the publication after peer review.

- The final published version features the final layout of the paper including the volume, issue and page numbers.

Link to publication

\footnotetext{
General rights rights.

- You may freely distribute the URL identifying the publication in the public portal. please follow below link for the End User Agreement:

www.umlib.nl/taverne-license

Take down policy

If you believe that this document breaches copyright please contact us at:

repository@maastrichtuniversity.nl

providing details and we will investigate your claim.
}

Copyright and moral rights for the publications made accessible in the public portal are retained by the authors and/or other copyright owners and it is a condition of accessing publications that users recognise and abide by the legal requirements associated with these

- Users may download and print one copy of any publication from the public portal for the purpose of private study or research.

- You may not further distribute the material or use it for any profit-making activity or commercial gain

If the publication is distributed under the terms of Article $25 \mathrm{fa}$ of the Dutch Copyright Act, indicated by the "Taverne" license above, 
Summary 


\section{Summary}

Chapter 1 presents the introductory background and premises upon which we laid and structured our research. It describes the rationale for undertaking our studies and generates the research questions based on the main pillars of this thesis: the magnitude and risk factors for intestinal parasitic infections (IPIs) and under-nutrition, protection against IPIs and under-nutrition through inexpensive and simple public health interventions, determining the association between IPIs, anaemia and diarrhoea and determining the universality of the effect of interventions among the study populations.

The chapter describes how IPIs and under-nutrition remain major health and socioeconomic challenges among underserved populations worldwide. Diseases caused by IPIs (both helminths and protozoa) and under-nutrition (both protein-energy malnutrition and micronutrient deficiencies) are of particular importance in terms of global burden, and their control has been recently recognised as a priority for achieving the United Nations Millennium Development Goals (MDGs).

IPIs and under-nutrition show similar geographic distribution, usually among poor populations which suffer from their combined effects. In such settings, infection and under-nutrition are highly interlinked. Children, particularly those of school-age, are heavily burdened by IPIs and malnutrition. They also serve as a source for the maintenance of IPI transmission. In endemic settings, children are continuously infected and re-infected with IPIs and this can eventually affect all aspects of their development. The number of IPIs affecting humans has increased following the emergence and expansion of the AIDS pandemic. A range of parasite species previously considered rare or zoonotic have become highly prevalent among humans and cause life-threatening illnesses in immunocompromised patients.

The high prevalence of infectious diseases and inadequate food intake has increased the prevalence of nutritional deficiencies among children in developing countries, resulting in health and development problems. Among the one billion people estimated to be affected by under-nutrition globally in 2010, $98 \%$ were from developing countries.

Micronutrient deficiencies also contribute significantly to the burden of undernutrition. Anaemia is a widespread form of micronutrient deficiency affecting more than 2.6 billion people worldwide. Although causes of anaemia vary depending on the local conditions, iron deficiency is the most important contributing factor. IPIs (such as hookworms, ascaris and schistosomiasis), chronic infections (such as HIV, malaria and tuberculosis) and lack of other micronutrients can also lower haemoglobin levels and 
increase the risk of developing anaemia. Children are among the most at-risk population for under-nutrition due to rapid growth stages and subsequent high nutritional requirements, combined with the increased risk of infection and poor dietary intake.

Despite the recent global interest in solving health problems of school-aged children, data on disease burden among these population groups are lacking in developing countries. The multi-factorial nature of health problems in this age group requires an integrated approach to solving the problem. The extent of health problems and contributing factors must be identified and addressed. Simple public health infection prevention measures also must be identified and integrated into the health intervention programs. An understanding of the infection and nutritional status of children and immunocompromised patients has far-reaching implications for health promotion and could provide valuable insight for decision makers in setting policy priorities and monitoring intervention programs.

Considering these issues, the studies in this thesis centred around three principle investigations. First, the magnitude of IPIs and associated risk factors were assessed among antiretroviral treated patients. Second, we investigated the prevalence and risk factors associated with IPIs, anaemia, and malnutrition in school-aged children. Third, based on the findings of these studies, we designed interventions that we believed could potentially alleviate risk factors for infection and under-nutrition, and assessed their impact in rural school-aged children. Based on the findings from this study, we further explored whether the impact of our interventions was similar among children despite differences in baseline demographic and disease characteristics, and assessed the pattern of associations between IPIs, diarrhoea, and anaemia among school-aged children.

The cross-sectional study conducted to assess the prevalence and associated risk factors for IPIs among antiretroviral-treated HIV/AIDS patients is presented in Chapter 2. A total of 384 patients receiving antiretroviral treatment (ART) were included in the study. Data on sociodemographic and personal hygiene and sanitation practice were collected from each participant using structured questionnaires. Parasitological surveys were completed on stool and urine specimens using direct microscopy and concentration techniques. Data on immunological profile and WHO disease staging was acquired from hospital records. The overall prevalence of intestinal parasitosis was $56 \%$ and no opportunistic gastro-intestinal parasites were detected. IPIs affected both genders equally except for Taenia species infections, whereby female participants had significantly less infections (OR: 0.34) than males. Intestinal parasitosis was associated with lower mean CD4+T-cell count and poor hygiene and sanitation practice. Lack of latrines and poor hand-washing with soap practice at critical times were significantly 
associated with higher E. histolytica/dispar (OR: 2.75 and OR: 2.67, respectively) and G. lamblia (OR: 2.08 and OR: 2.46, respectively) infections.

In our study, IPIs were widespread among the study group, with an overall prevalence higher than several similar studies from the country and other studies elsewhere. Nonopportunistic protozoan parasites, E. histolytica/dispar and G. lamblia, were the most frequent parasites encountered, followed by the zoonotic tapeworms, Taenia species. In this chapter it is highlighted that only extracellular gastrointestinal parasites were detected. Following the advent of highly active ART, the immune status of patients has improved, subsequently increasing protection against opportunistic infections and improving quality of life. IPIs may contribute to the morbidity of HIV/AIDS patients in endemic areas and their early identification could be important to improving the quality of life of patients under ART. Additionally, increased personal hygiene and sanitation can reduce faecal-oral transmission of IPIs among these populations.

Chapter $\mathbf{3}$ presents the results of a cross-sectional study on the risk factors associated with IPIs, anaemia and malnutrition among school children from urban and rural areas of northern Ethiopia. This study involved 600 school children from 12 primary schools. Demographic and socioeconomic data were collected using structured questionnaires uploaded onto a mobile phone using Datadyne Episurveyor software. Anthropometric data were collected by recording age, weight (to the nearest $0.1 \mathrm{~kg}$ ), and height (to the nearest $0.1 \mathrm{~cm}$ ) of the children. Parasitological analysis was carried out on fresh stool and urine specimens using direct saline wet mount, formalin ethyl acetate concentration and the Kato-Katz techniques. For helminthic infections, the total number of eggs detected on each slide was counted and the number of eggs per gram of faeces (epg) was calculated to determine egg burden. Urine specimens with positive screens for microhaematuria and those with gross haematuria were subjected to microscopic diagnosis for S. haematobium ova using urine sedimentation method. Haemoglobin concentrations of study participants were determined in finger prick blood using a HemoCue analyser.

Our analysis has shown a high prevalence of parasitic infections (72\%) and energyprotein malnutrition, including stunting (35\%) and thinness (34\%) in our study populations. The protozoan parasite, E. histolytica/dispar, was the most frequently isolated parasite followed by the Cestodes - H. nana. No S. haematobium ova were identified. Egg concentrations for each identified helminthic infection were of light intensity. Anaemia prevalence in the study group was of a mild public health importance (11\%). Although there were slight differences between urban and rural schools, problems of infection and under-nutrition were of the same magnitude. Overall, children with poor personal hygiene habits had higher prevalence of intestinal parasitosis. Similarly, the prevalence of anaemia and protein-energy malnutrition was 
higher among unhygienic children. Use of smart phone technology in the study improved data collection time and quality, and enabled us to develop simple data collection forms. Their potential use for field surveys in resource-limited settings is worth further investigation. Our study suggested the need for improved personal hygiene practices through increased access to hygiene facilities for hand washing and proper waste disposal. We identified a need for randomised trials to address the causal relationship between personal hygiene, parasitic infection, and malnutrition, which we subsequently conducted in Chapter 4.

Based on our findings from Chapter 3, we conducted a factorial randomised controlled trial among rural school-aged children to assess the impact of hand-washing with soap and nail clipping in the prevention of intestinal parasite re-infection, reduction of worm burden and anaemia prevalence. This study is described in Chapter 4. A study population of 367 school-aged children (aged 6-15) were randomised to one of four groups defined by a $2 \times 2$ factorial design: hand-washing with soap; nail clipping; handwashing with soap and nail clipping; or standard habit and practice controls. Eligible children for the study were aged 6-15 years, screened negative for IPIs, were planning to continue residing in the same house for the study period, and had produced an informed consent signed by their parents or guardians.

Random allocation of study participants to the intervention and control arms was completed using computer generated random numbers. The principal purpose of the trial and assignment sequence was concealed from researchers recruiting the study participants. Laboratory personnel were blinded to group assignments and to the assessment outcomes. Following acquisition of a signed informed consent and before random allocation to intervention groups, a series of parasitological screening and treatment administration steps were conducted. Children who screened negative were randomly assigned to an intervention group and monitored for six months. At baseline, data on sociodemographics, personal hygiene and sanitation practices were collected using structured questionnaires. Finger prick blood was collected and haemoglobin concentrations were determined using a HemoCue analyser.

Interventions were implemented at the household level and randomly selected schoolaged children within a household were classified as a study unit. Plain soaps were supplied to the hand-washing intervention households, who were encouraged to wash their hands with soap and water at critical times. New nail clippers were provided for the children allocated to the nail clipping intervention, and nail clipping was performed on a weekly basis by the fieldworkers. Children in the control arm were neither encouraged nor discouraged to wash and/or clip their nails. All households were visited with equal frequency on a weekly basis. Control households were frequently checked 
for the presence of soap for hand-washing and nail clippers during the weekly visits to check for contamination.

The trial concluded at the end of six months as scheduled. Stool specimens were collected and analysed by well-trained blinded laboratory personnel using direct saline wet mount, formalin ethyl-acetate concentration technique, and the Kato-Katz technique. Worm burden (infection intensity) for helminthic parasites was determined by calculating numbers of eggs per gram (epg) of stool. A child was classified as reinfected if an infection was detected by any methods used. After the trial, haemoglobin concentration was determined using the same procedure in Chapter 3. Haemoglobin readings were adjusted for altitude, and anaemia was defined for respective age and gender groups based on the WHO cut-off values.

The primary hypothesis of the study stated that hand-washing with soap and nail clipping would significantly reduce the prevalence of intestinal parasite re-infection rates and worm burden among the study population of school-aged children. Throughout the study period, only two children were lost to follow-up. Two others were excluded at the beginning of the study as they screened positive for intestinal parasitosis after successive treatments.

Regarding the study's primary outcome, only $14 \%(26 / 185)$ of children in the handwashing with soap intervention were re-infected compared to $29 \%$ (53/182) of children in the control group (OR 0.32). Similarly, the prevalence of re-infection was lower among children in the nail clipping group, at $17 \%$ (33/189), compared to $26 \%(46 / 178)$ of children in the control arm (OR 0.51). Further, a significant reduction in worm burden was observed among children in the hand-washing group than the control group (mean epg $=4.1$ vs. $11.8, p=0.005$ ), and nail clipping group than the control group (mean epg 3.4 vs. 12.6, $p=0.001)$. At the end of the trial, $13 \%(24 / 185)$ of children in the hand-washing intervention were anaemic compared to $23 \%(41 / 182)$ in the control group (OR 0.39). There was also a reduction in the prevalence of anaemia among children of the nail clipping intervention; however the observed difference did not reach statistical significance.

The six-month hand-washing with soap and weekly nail clipping interventions demonstrated a significant reduction in intestinal parasite re-infection rates and the size of worm burden acquired after a successful treatment. A significant reduction in the prevalence of anaemia was also observed in children of the hand-washing with soap intervention. Given that school-aged children bear peak worm intensity in a community and that the size of the worm burden is the central determinant of transmission dynamics, proper hand-washing with soap and weekly nail trimming could 
have potential flow-on benefits to the community by reducing parasite transmission, in addition to immediate benefits in improving the health of children under consideration.

Our data showed that hand-washing and nail clipping were efficacious, however, our trial included rigorous follow-up and monitoring which involved high human resource investment. The long-established habitual and culturally embedded practices on personal hygiene and sanitation among children and households might require additional methods to influence behavioural changes and hence would make large scale implementations of the interventions more expensive. However, as labour is still very inexpensive in Ethiopia and other low income countries, national campaigns could be organised to implement hand-washing with soap at key times and weekly nail clipping through house-to-house education. Hand-washing and nail clipping interventions could also be integrated into existing community health programmes that reach inaccessible impoverished populations through house-to-house visits as their outreach activities. The next essential step should focus on implementing pragmatic studies that investigate the performance of the interventions under circumstances that more closely approach the real and usual conditions and developing additional more effective approaches to promote hand-washing with soap and nail clipping at larger scale. Chapter 5 describes the pattern of associations between IPIs, anaemia and diarrhoea, and factors predicting IPIs and under-nutrition among school-aged children. We also explored whether the observed effects of interventions in the study population described in Chapter 4 could apply to children of different demographic and disease backgrounds.

The study design, intervention, follow-up, and laboratory investigation procedures are described in Chapter 4. The incidence of diarrhoea from all study households was documented by the field workers using a separate questionnaire during weekly household visits. The presence of diarrhoea was determined through corresponding with either the parents or the child. Two independent and trained data collectors took anthropometric measurements and the average recorded. Anthropometric measurements were converted into BMI-for-age $Z$ scores using WHO AnthroPlus software. Children below $-2 Z$ scores were classified as thin.

Our findings demonstrated significant associations between IPIs, anaemia and diarrhoea among children. No trends in associations were observed between baseline demographic characteristics, IPIs, and malnutrition among the children. Only few potential effect modifiers were identified. Young child age was a significant predictor for anaemia (OR 1.82). Having young mothers predicted lower history of IPIs (OR 0.50). Living in small-sized families (OR 2.40), and history of anaemia (OR 2.08) and IPIs (OR 1.98) at baseline were significant predictors of higher risk of IPIs at follow-up. Handwashing with soap at key times and weekly nail clipping were effective in reducing 
intestinal parasite re-infection rates in the study population. Our analysis suggests benefits from the interventions would likely be universal among the study groups.

Our findings in this chapter emphasise that hand-washing with soap and nail clipping can universally be used as infection prevention measures among school-aged children despite baseline demographic differences. Given that intestinal parasitosis, anaemia and diarrhoea have been independently associated, a holistic and integrated approach should be implemented to break the vicious cycle for the long-term health benefits of the population.

In the final chapter of this thesis, Chapter 6, we present the overall major findings, methodological considerations, and conclusions of the studies presented in this thesis. The major discussion points in this chapter are presented in three main areas (1) the prevalence and associated factors predicting intestinal parasitosis and under-nutrition among vulnerable populations, notably HIV/AIDS patients and school children; (2) the impact of simple hand hygiene interventions (hand-washing with soap at key times and weekly finger nail clipping) on the prevention of intestinal parasite re-infection, reduction of infection intensity and anaemia prevalence among rural school-aged children; and (3) identifying patterns of associations between IPIs, anaemia and diarrhoea among school-aged children, and an analysis of the impact of hand-washing and nail clipping on IPIs across different subgroups of children.

In this chapter we also discuss the widespread prevalence of IPIs and under-nutrition among vulnerable populations in the study area. We further illustrate that observed high prevalence rates were associated with poor hygiene and sanitation practices. The findings of our randomised controlled trial were also highlighted. Challenges and opportunities for large scale implementation of simple hygiene interventions were illustrated with due emphasis. The chapter closes with nine major conclusive remarks and recommendations, and a research plan that could be used for optimum prevention of IPIs and under-nutrition among school-aged children in low-income countries. 


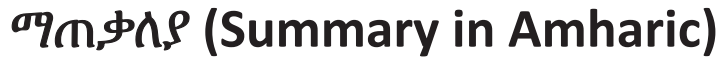




\section{${ }^{a q}, \Phi \lambda, \rho$ (Summary in Amharic)}

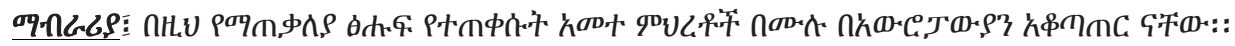

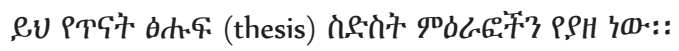

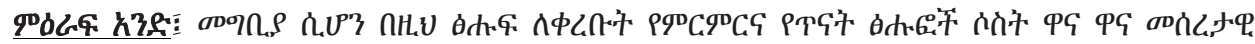

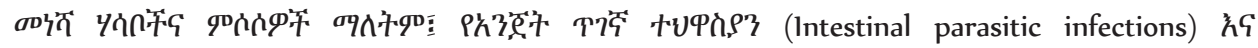

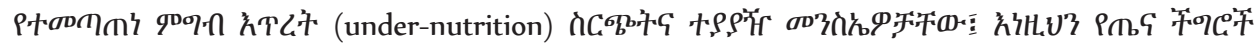

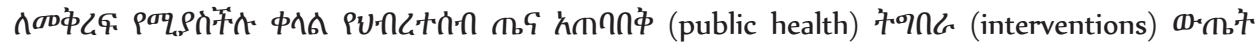
वD79D79

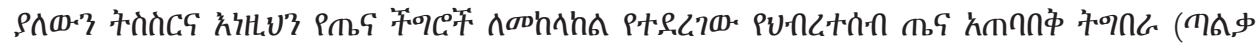

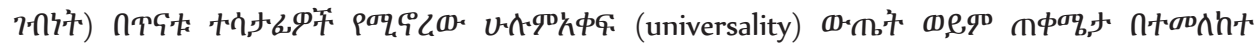

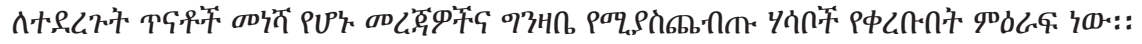

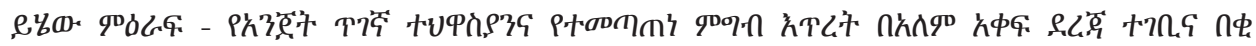

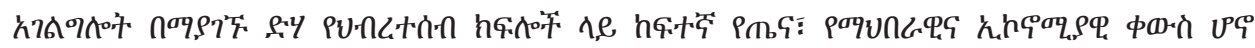

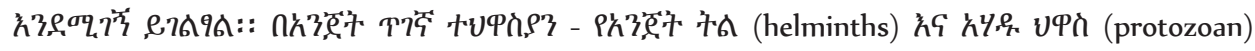

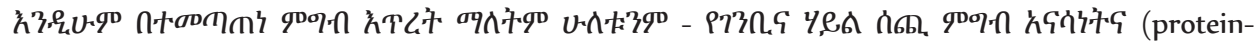

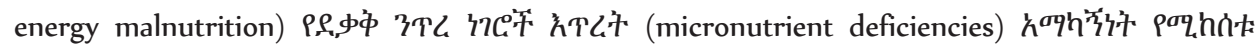

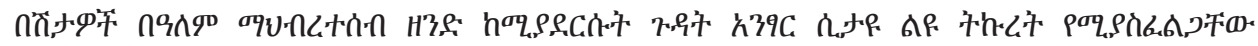

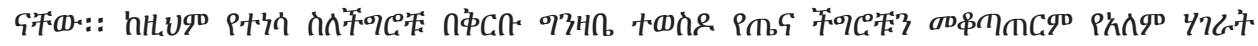

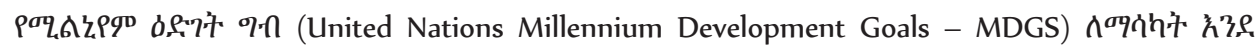
ф.,

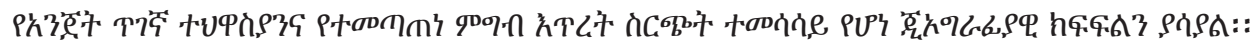

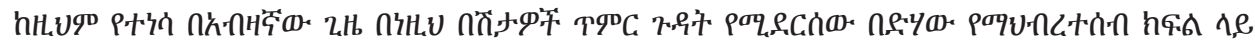

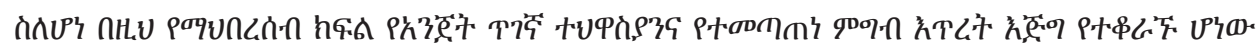

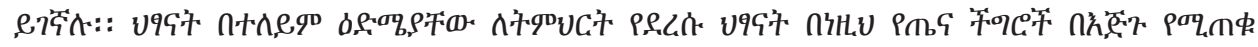

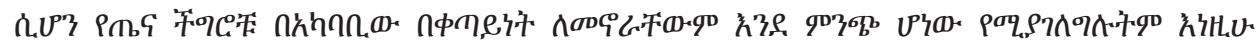

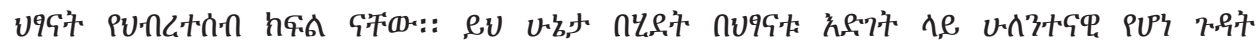

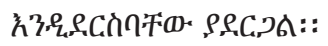

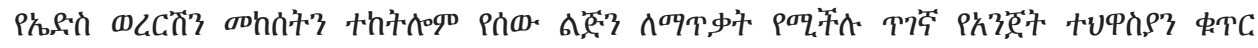

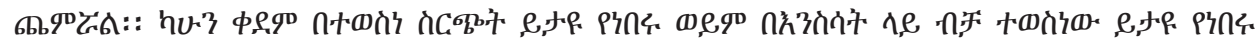

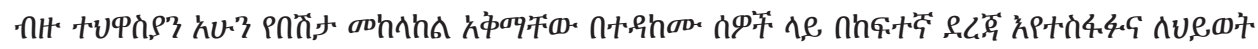

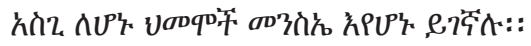

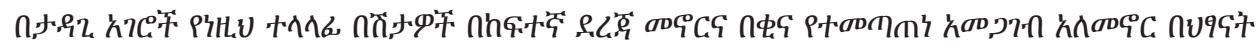

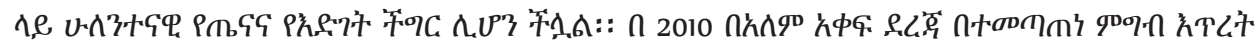

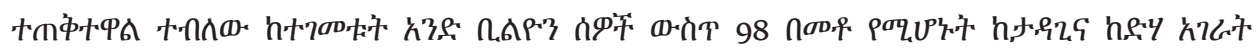
U. 


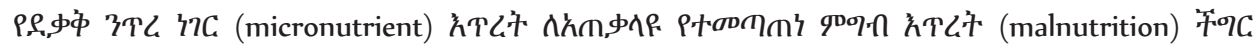

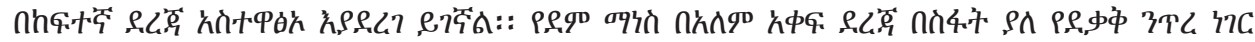

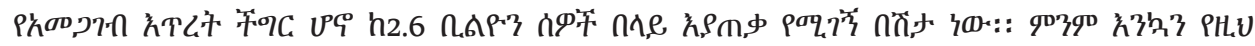

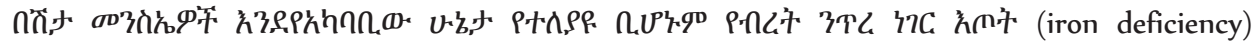

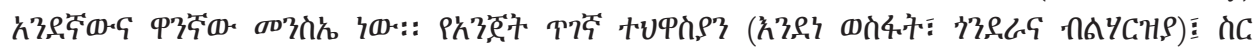

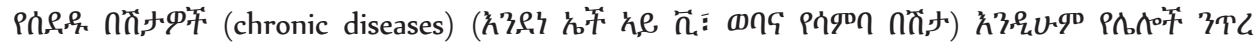

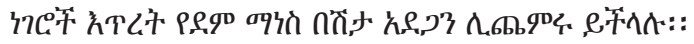

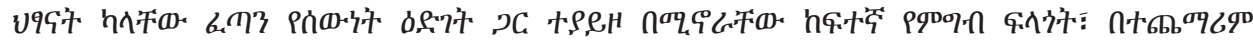

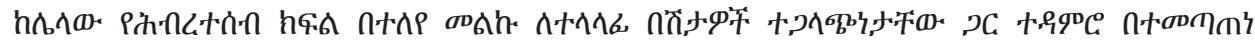

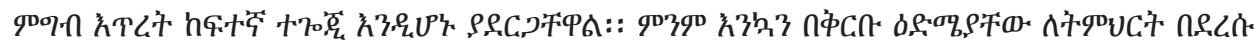

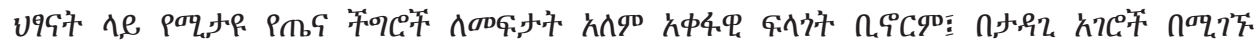
o.

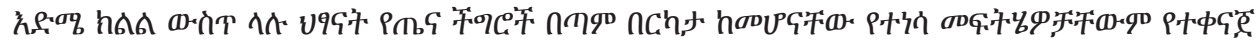

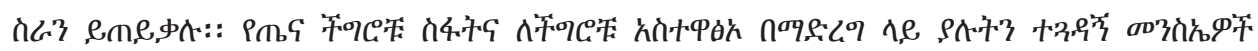

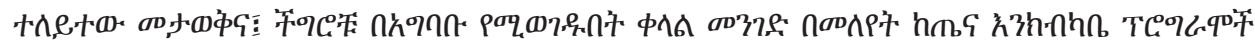

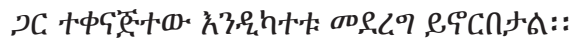

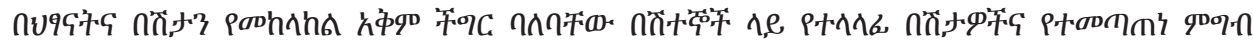

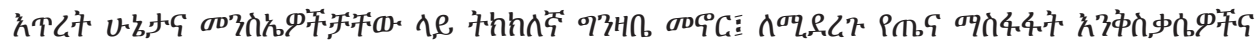

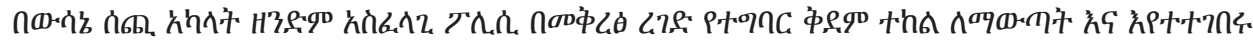

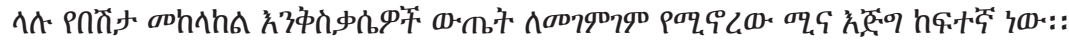

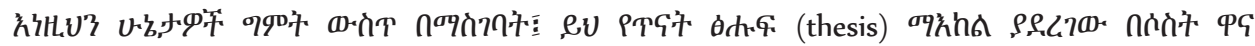

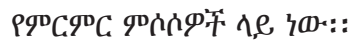

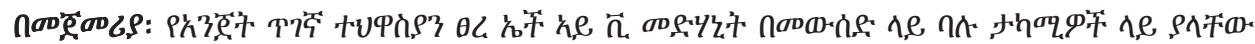

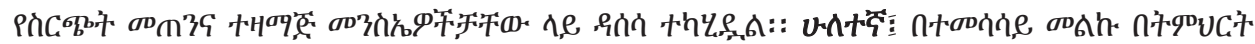

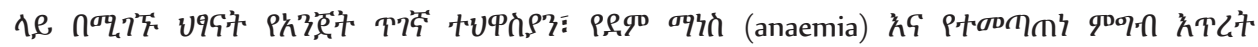

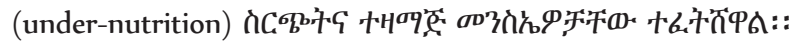

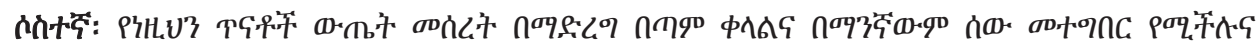

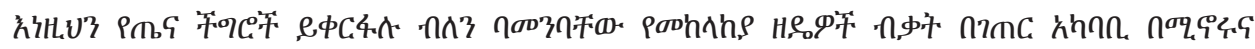

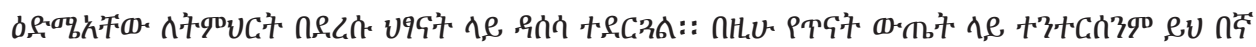

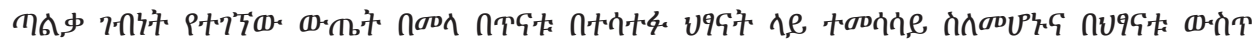

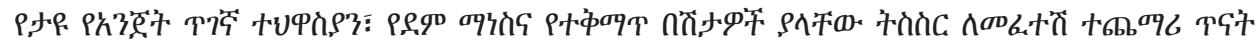
中hY Q

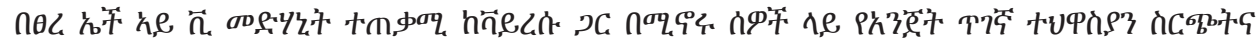

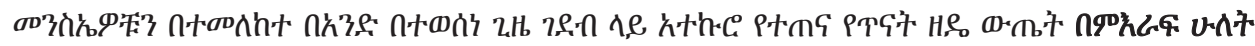

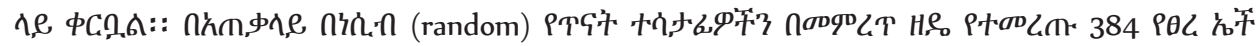

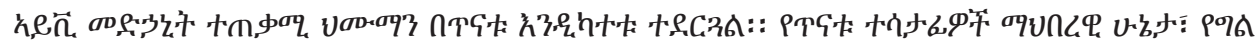




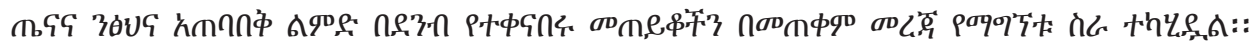

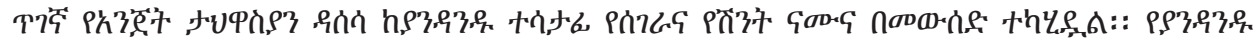

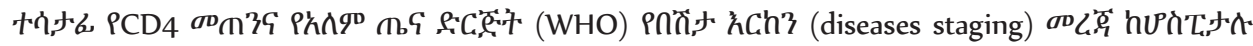

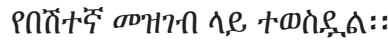

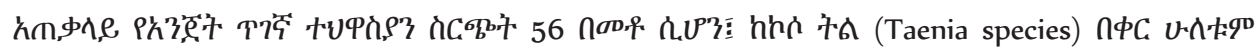

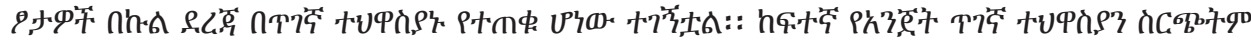

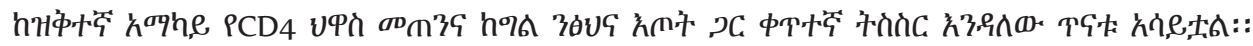

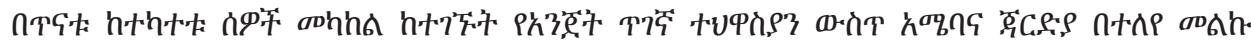

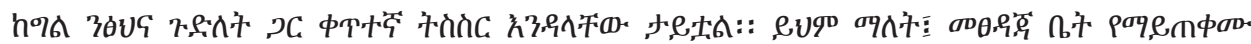

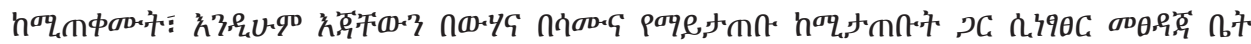

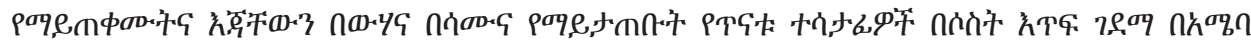

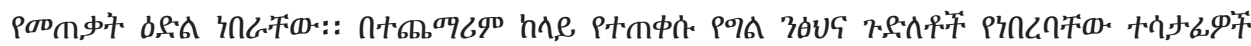

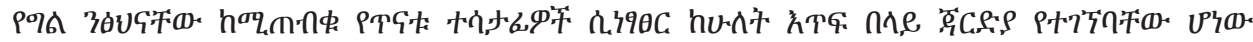

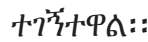

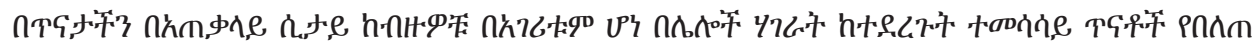
тา'

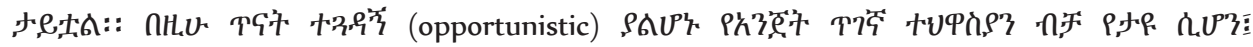

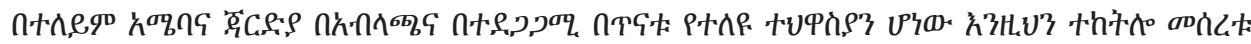

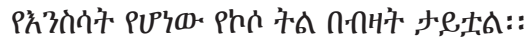

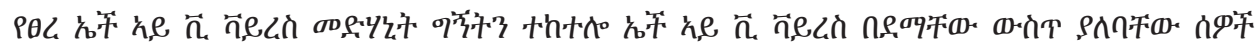

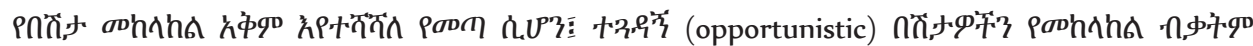
え९њ

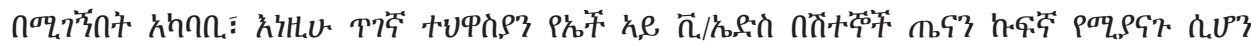

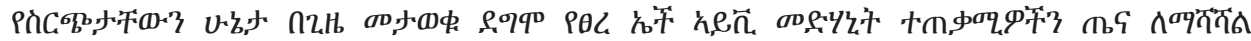

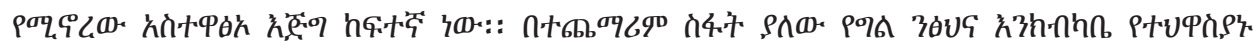

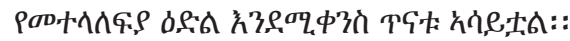

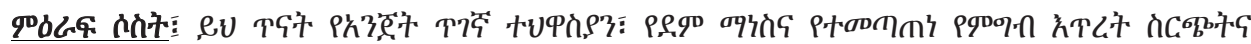

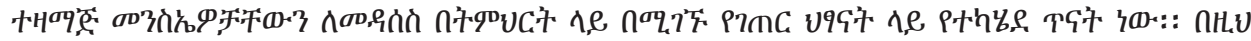

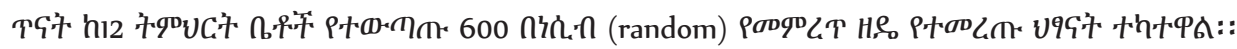

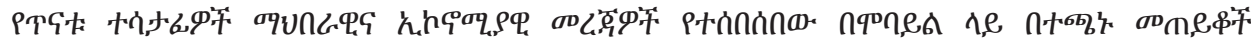

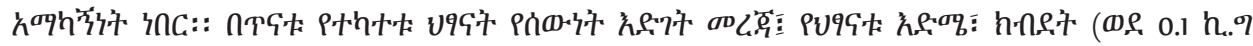
ח

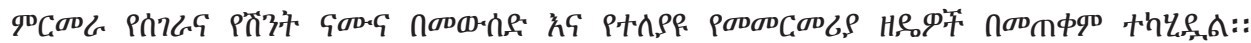

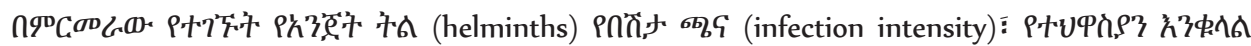

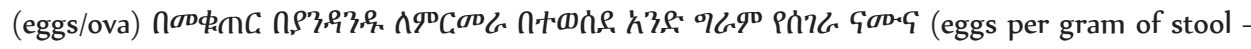
epg) 


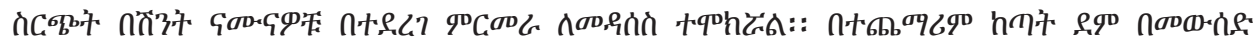

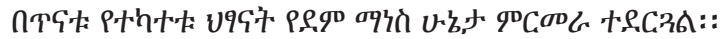

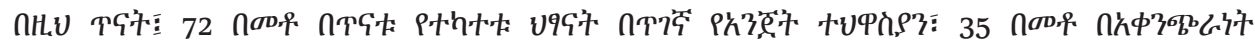

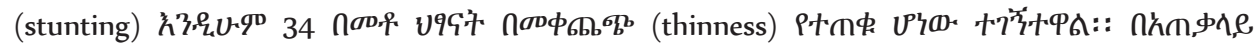

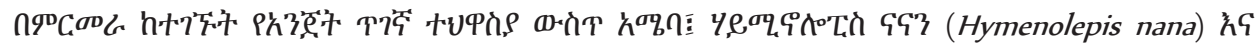

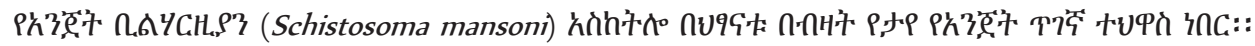

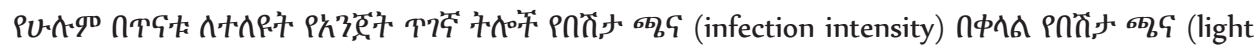

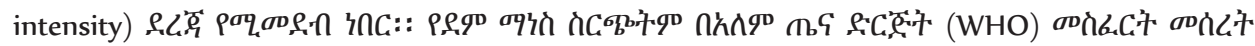

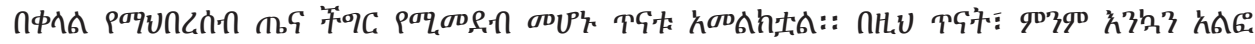

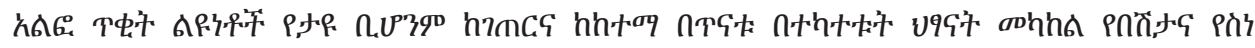

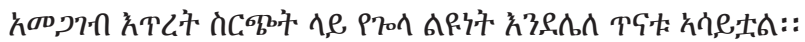

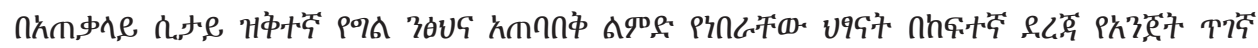

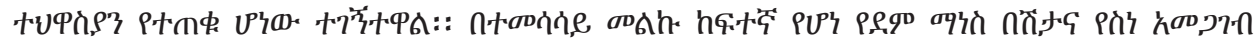

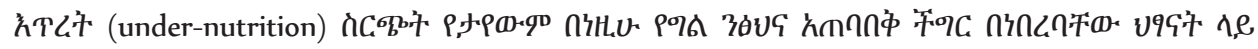
inc: :

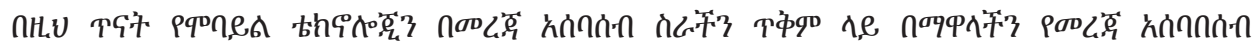

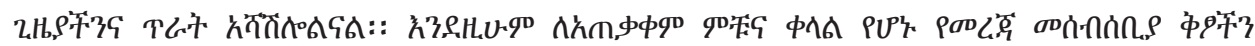

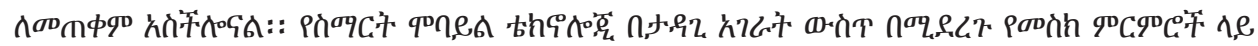

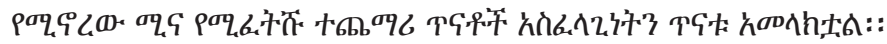

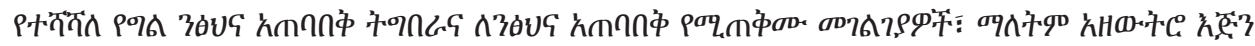

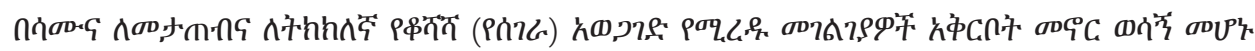

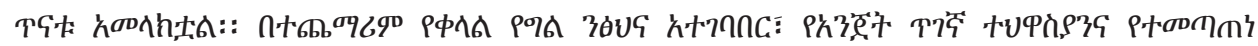

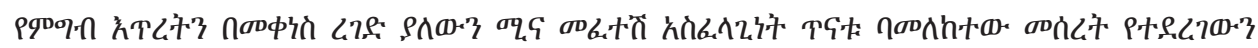

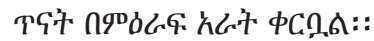

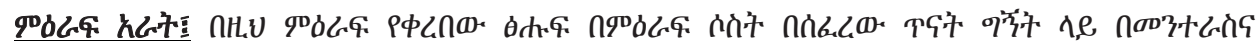

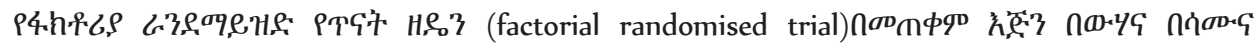

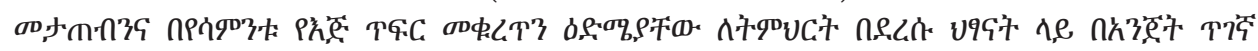

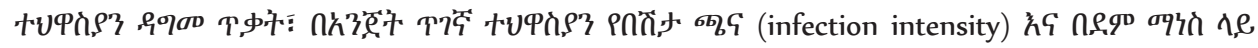

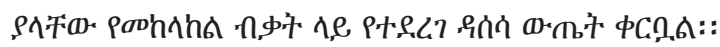

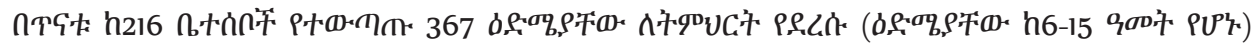

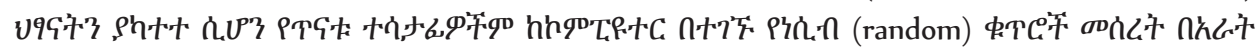

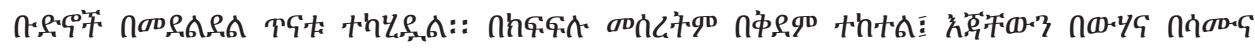

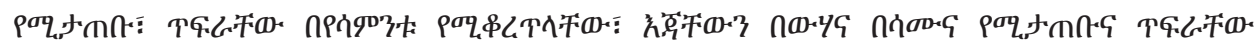

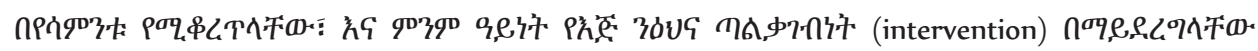

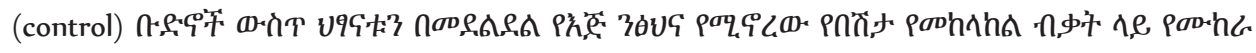
Tद⿱ + +h 


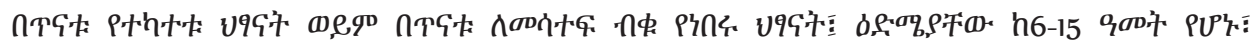
nTG中 ad

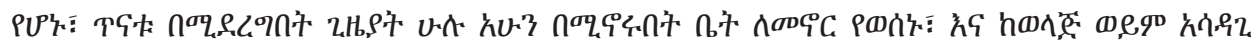

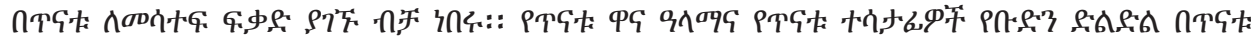

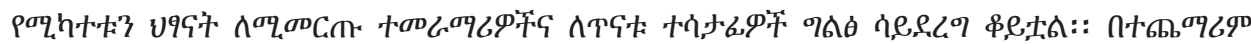

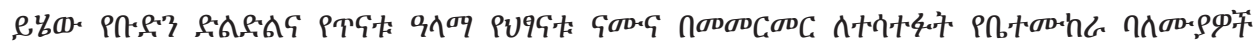

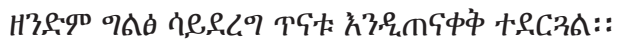

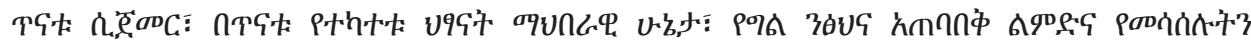

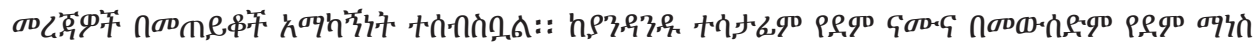

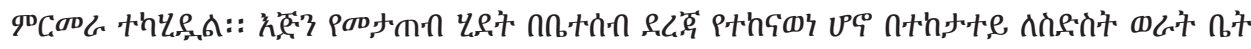
त

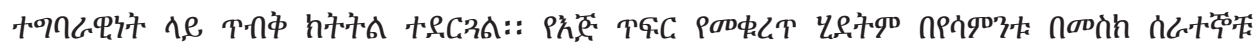

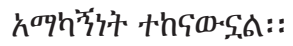

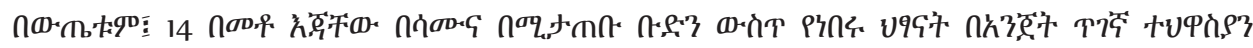

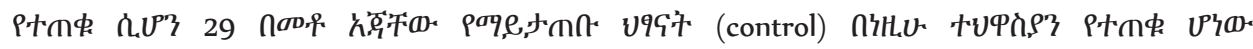

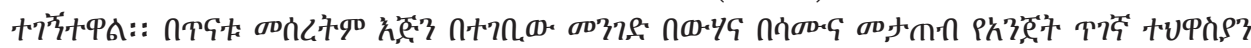

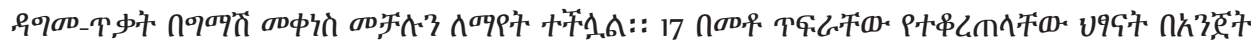

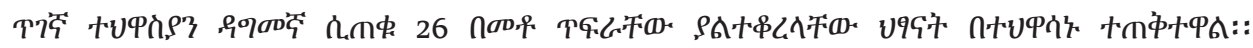

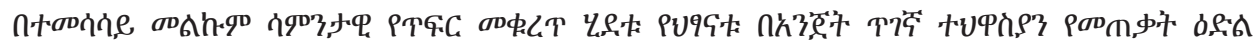

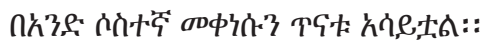

กヤณ"

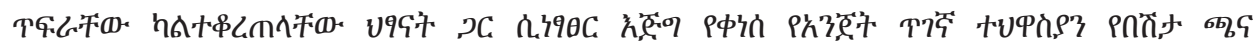

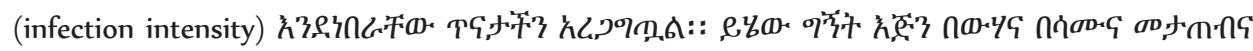

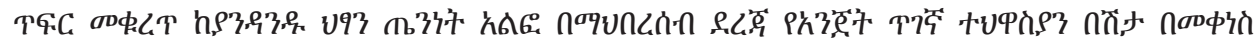

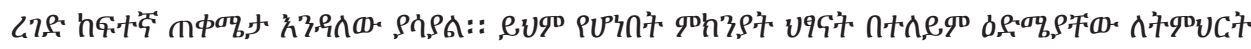

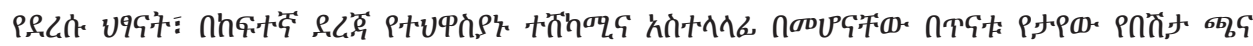

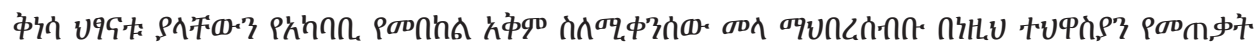

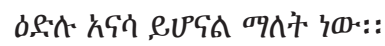

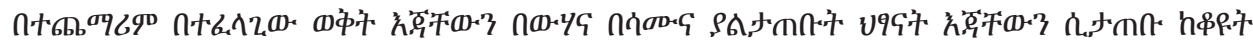

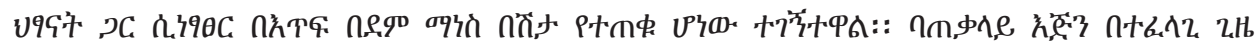

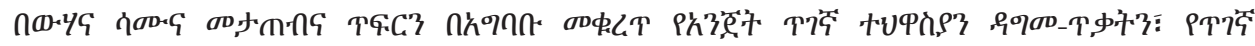

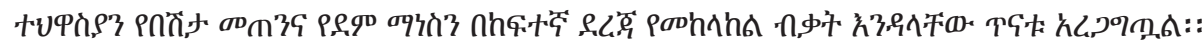

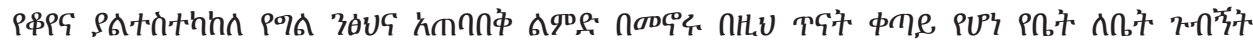

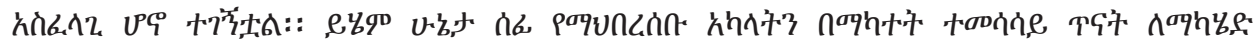

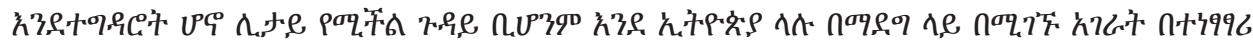

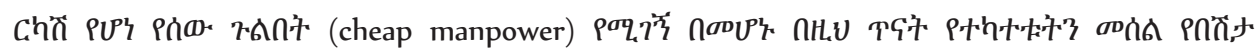




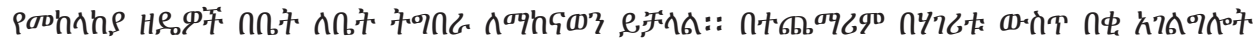

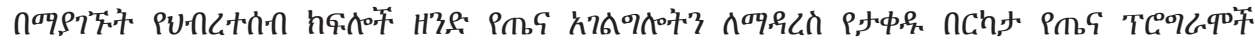

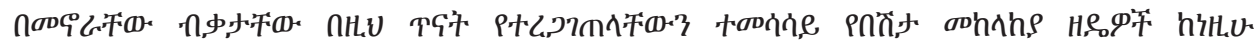

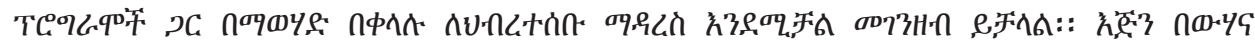

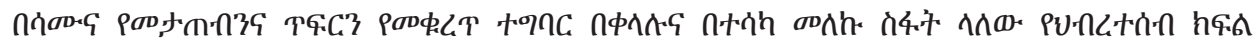

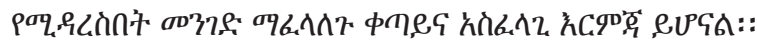

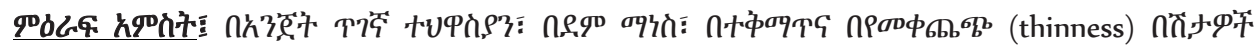

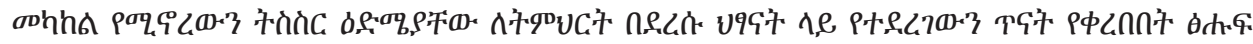

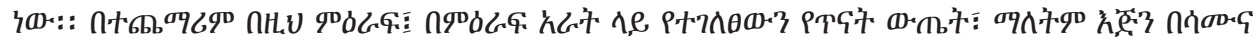

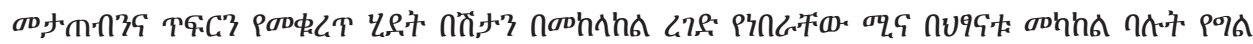

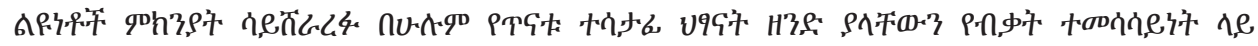

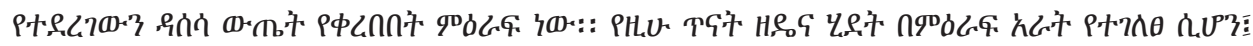

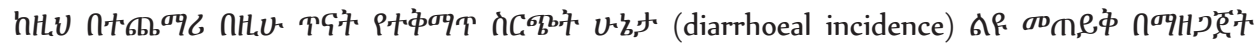

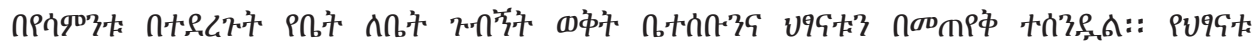

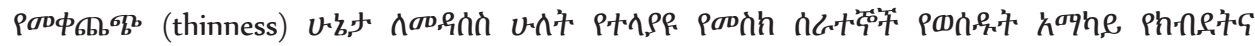
P中od +P.C. $\operatorname{Cin}:$ :

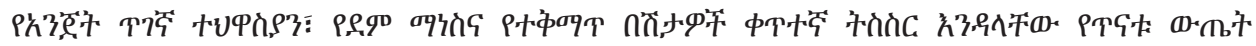

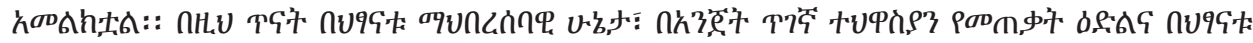

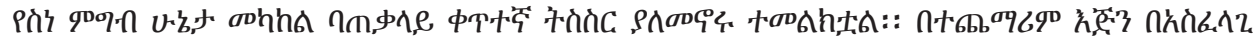

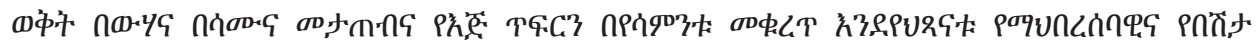

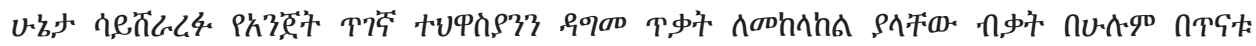

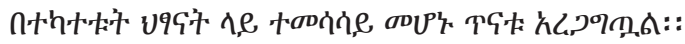

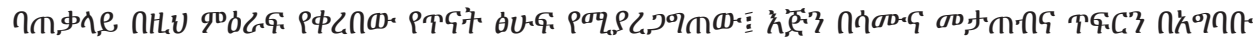

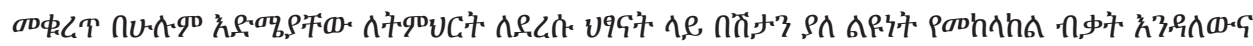

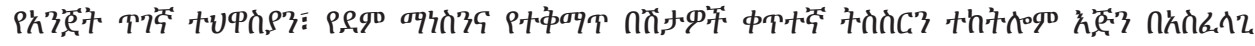

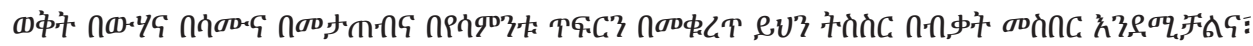

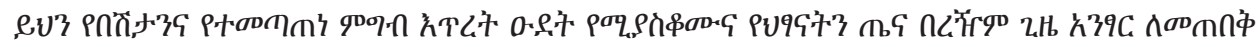

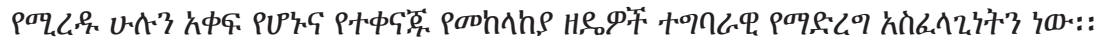

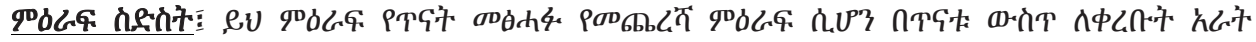

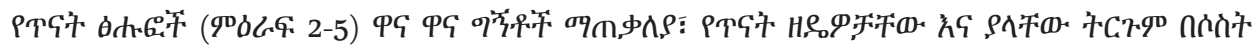

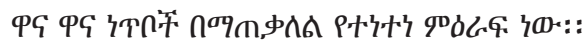

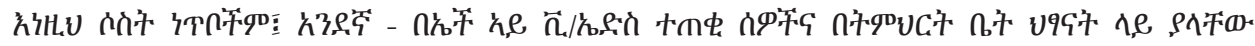

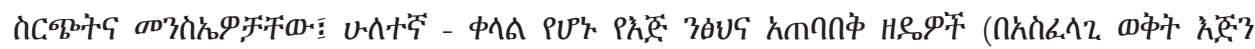

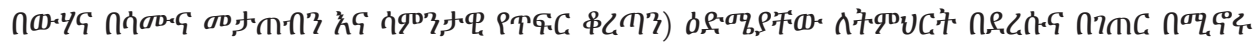
v9द市

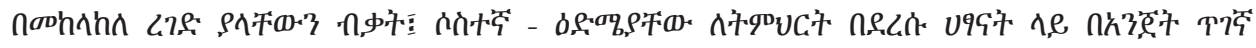




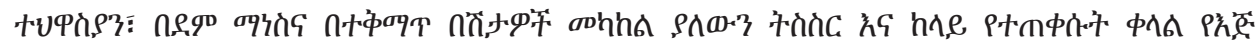

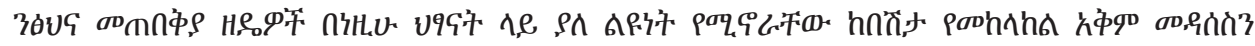

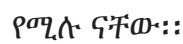

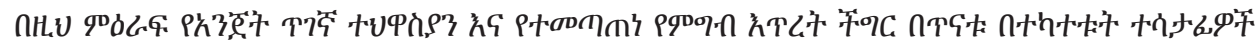

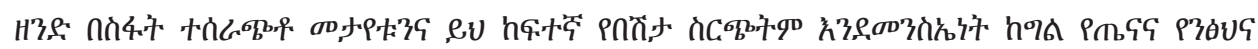

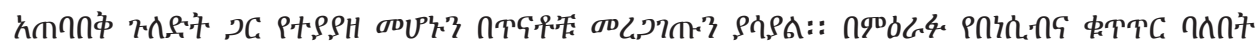

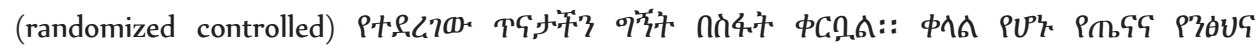

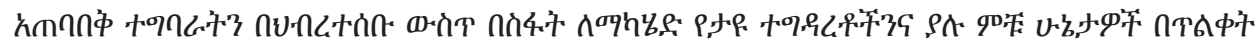

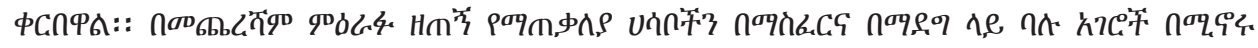
d.P.

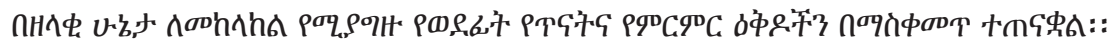


Resumen (Summary in Spanish) 


\section{Resumen (Summary in Spanish)}

En el Capítulo primero se expone la introducción de este proyecto de investigación y se presentan los fundamentos sobre los que se han establecido la hipótesis y los objetivos del estudio. En este capítulo se describe la relevancia de de las infecciones parasitarias intestinales (IPI) en amplios grupos de población, especialmente niños, en Etiopía y gran parte de la población mundial. Los estudios realizados en esta tesis se han centrado en torno a tres cuestiones principales: 1) la caracterización de las infecciones parasitarias intestinales (IPI) y los factores de riesgo asociados en personas con la infección HIV/SIDA en tratamiento con antirretrovirales; 2) la caracterización de la prevalencia y factores de riesgo asociados con las IPI, la anemia y la desnutrición en los niños en edad escolar; 3) el diseño e implementación de un ensayo clínico para demostrar la eficacia de intervenciones de salud pública sencillas, como el lavado de manos con jabón y el recorte de uñas, en la reducción de las IPI y la desnutrición en niños en edad escolar.

El capítulo segundo se basa en el artículo publicado en la revista International Journal of STD \& AIDS con el título "Risk factors for intestinal parasitosis among antiretroviral treated HIV/AIDS patients in Ethiopia".

En este primer trabajo hemos analizado la prevalencia y los factores de riesgo asociados a las infecciones parasitarias intestinales en personas infectadas con HIV/ SIDA. Un total de 384 personas con HIV/SIDA en tratamiento antirretroviral (ART) fueron incluidos para este estudio. Mediante cuestionarios estructurados recogimos los datos sociodemográficos de este grupo de persobas. Los análisis parasitológicos en muestras de heces y orina se realizaron mediante técnicas de microscopía directa y de concentración, mientras que la información sobre el perfil inmunológico y la evolución de la enfermedad se obtuvo a partir de las historias clínicas hospitalarias. En este estudio, observamos que la prevalencia de las IPI era de un 56\% (95\% intérvalo de confianza $51 \%$ to $61 \%$ ). Las IPI se asociaronde forma significativa a un menor recuento de células T CD4 + $(p=0.002)$, pero no con el estadío de la enfermedad.

La escasez de letrinas y una mala higiene de manos se asociaron de forma significativa con una mayor prevalencia de infecciones por E. Histolytica /dispar (OR: 2,75 y OR: 2,67, respectivamente) y G. lamblia (OR: 2,08 y OR: 2,46, respectivamente). Los parásitos protozoarios no oportunistas como la E. histolytica / dispar y G. lamblia, fueron los parásitos más frecuentes encontrados, seguidos por las tenias zoonóticas.

En resúmen, la mala higiene personal y las deficientes condiciones sanitarias contribuyen de forma significativa a la alta prevalencia de IPI en pacientes con HIV/SIDA. Las infecciones parasitarias intestinales contribuyen a la morbilidad de los 
pacientes con VIH / SIDA y su cribaje rutinario en la clínica es acosnsejable para mejorar la calidad de vida de dichos pacientes.

El capítulo tercero se basa en el articulo publicado en la revista Pathogens and Global Health con el título "Risk factors for intestinal parasitosis, anemia, and malnutrition among school children in Ethiopia".

En este capítulo presentamos los resultados de un estudio sobre los factores de riesgo asociados a las infecciones parasitarias intestinales, la anemia y la desnutrición en los niños en edad escolar del norte de Etiopía.

Para este estudio, reclutamos de forma aleatoria a 600 niños distribuidos en 12 escuelas primarias en zonas rurales del norte de Etiopía. Los datos demográficos y socioeconómicos fueron obtenidos mediante cuestionarios estructurados utilizando aplicaciones específicas de smartphone. El análisis parasitológico en heces se realizó mediante los métodos de análisis directo en fresco, concentración y Kato-Katz. Las muestras de orina se utilizaron para el examen de huevos de Schistosoma haematobium. Asimismo, para las infecciones por helmintos, se analizó el número total de huevos y por gramo de heces. La concentración de hemoglobina se determinó mediante un analizador HemoCue.

Nuestros resultados indicaron que la prevalencia de parasitosis intestinal en este grupo de estudio era de un $72 \%$ (95\% confidence interval $(\mathrm{Cl}): 66-76 \%)$. El parásito protozoario, E.histolytica, fue el parásito más frecuentemente aislado, seguido de los cestodos - H. Nana. La prevalencia de anemia y retraso de crecimiento fué de un $11 \% \%$ (95\% Cl: 8-13\%), y un 35\% (95\% Cl: 31-38\%) respectivamente. Aunque hubo pequeñas diferencias entre las escuelas urbanas y rurales, los problemas de infección y la desnutrición fueron de la misma magnitud. Los niños con peores hábitos de higiene personal mostraron una mayor prevalencia de IPI, anemia y desnutrición.

En resumen, el uso de nuevas aplicaciones de teléfonos móviles para la recogida de datos en el estudio nos ha permitido un análisis de datos más eficiente y rápido. Nuestro estudio refuerza la necesidad de mejorar las prácticas de higiene personal en los niños promoviendo el lavado de manos generalizado y un mejor acceso a los servicios de saneamiento para reducir las infecciones parasitarias intestinales, la anemia y la desnutrición.

El capítulo cuarto, se basa en el articulo enviado a revisión a la revista PLoS Medicine con el título Hand washing with soap and nail clipping: effect on intestinal parasitosis among school-aged children: a factorial randomised controlled trial". 
En este estudio evaluamos la eficacia de dos intervenciones de salud pública, el lavado de manos con jabón y el recorte de uñas, en la prevalencia e intensidad de las infecciones parasitarias intestinales en niños en edad escolar. Para ello planteamos un estudio factorial $2 \times 2$ con grupo control y aleatorizado. Se reclutaron un total de 369 niños, entre 6-15 años, seleccionados de forma aleatoria en 12 escuelas del norte de Etiopía. Todos los sujetos del estudio fueron monitorizados previamente para ver si presentaban IPI y asignados a alguno de los cuatro brazos del estudio: (a) lavado de manos con jabón; o (b) recorte de uñas; o (c) lavado de manos con jabón y recorte de uñas; (d) grupo control. A los seis meses de seguimiento, se realizó un examen de muestras fecales mediante técnicas de concentración directa y de Kato-Katz. La hemoglobina se analizó con un espectrómetro HemoCue.

Las objetivos primarios del estudio fueron la prevalencia e intensidad de la reinfección parasitaria intestinal. Nuestros resultados indicaron que un $14 \%$ ( $95 \% \mathrm{Cl}$ : $9 \%$ to $19 \%)$ de los niños en el grupo de lavado de manos con jabón se reinfectaron en comparación con el $29 \%$ del grupo control ( $95 \% \mathrm{Cl}$ : $22 \%$ to $36 \%$ ) (OR 0.39 ). De forma similar, un $17 \%$ (95\% Cl: $12 \%$ to $22 \%$ ) del grupo de recorte de uñas se reinfectaron en comparación con el $26 \%$ del grupo control ( $95 \% \mathrm{Cl}: 20 \%$ to32\%) (OR 0.57). Asimismo, se observó una reducción significativa en la media de huevos por gramo en las heces, tanto en el grupo de lavado de manos con jabón (54 vs. 82 epg, $p=0.001$ ) como en el grupo de recorte de uñas (53 vs. $90, p=0.032$ ). Un $13 \%$ (95\% Cl: $8 \%$ to $18 \%$ ) de los niños en el grupo de lavado de manos presentaban anemia en comparación con el $23 \%$ ( $95 \% \mathrm{Cl}$ : $17 \%$ to $29 \%$ ) en el grupo control (OR 0.49).

El lavado de manos y el recorte de uñas disminuyó de forma significativa la reinfección parasitaria intestinal y la intensidad de la carga parasitaria. Asimismo, el lavado de manos redujo la prevalencia de anemia. Estos datos sugieren la necesidad de promover de forma más eficaz y generalizada el lavado de manos y el recorte de uñas en niños en edad escolar.

El capítulo quinto se basa en el artículo en revisión con el título "Associations between intestinal parasitic infections, anemia, and diarrhoea among school-aged children, and the impact of hand-washing and nail clipping"

En este estudio se analizaron: 1) las asociaciones entre las IPI, la anemia y la diarrea en niños de edad escolar; 2) los factores que pueden predecir las IPI y la desnutrición; y 3) el impacto del lavado de manos y el recorte de uñas en niños con diferentes situaciones demográficas basales.

Los datos de este trabajo forman parte del ensayo aleatorizado descrito en el capítulo anterior, donde evaluábamos el impacto del lavado de manos y el recorte de uñas en la 
reinfección parasitaria intestinal. Las asociaciones entre las IPI, anemia y diarrea y otras características demográficas basales se analizaron mediante modelos estadísticos de regresión binaria y regresión logística múltiple. Nuestros resultados demostraron asociaciones significativas entre las IPI, la anemia y la presencia de diarrea. No se observaron tendencias en las asociaciones entre las características basales demográficas, las IPI y la desnutrición. La edad del niño fue un factor predictivo significativo de anemia (OR 1,82); Las familias de menor tamaño (OR 2,40), anemia (OR $2,08)$ y la presencia de IPI $(O R 1,98)$ al inicio del estudio fueron predictores significativos de mayor riesgo de IPI tras la intervención.

En conjunto, estos resultados, sugieren que el lavado de manos con jabón y recorte de uñas son eficaces medidas de prevención de las infecciones parasitarias intestinales en los niños en edad escolar.

En el capítulo sexto, discutimos las principales aportaciones y lecciones del estudio, especialmente: (1) la prevalencia y los factores asociados a la infecciones parasitarias intestinales y la desnutrición en poblaciones vulnerables, en particular los pacientes con VIH / SIDA y los niños en edad escolar; (2) el impacto de simples intervenciones de higiene, como el lavado de manos con jabón y el recorte de uñas, en la prevención de la reinfección parasitaria intestinal, la disminución en la intensidad de la infección y de la prevalencia de la anemia entre los niños en edad escolar; y (3) la identificación de los patrones de asociación entre la IPI, la anemia y diarrea. Asimismo, al final de este capítulo, se resúmen las principales observaciones de nuestros trabajos y un grupo de recomendaciones para la mejor prevención de las infecciones parasitarias intestinales y la desnutrición en los niños en edad escolar en paises en desarollo. 